\title{
Decision Making in Designing and Choice of Dryer for Tropical Agricultural Crop
}

\author{
Tchamye Tcha-Esso Boroze ${ }^{1 *}$, Jean-Michel Meot ${ }^{2}$, Yaovi Ouézou Azouma ${ }^{3}$, Hélène Desmorieux ${ }^{4}$ \\ and Kossi Napo ${ }^{1}$ \\ 'Université de Lomé, Faculté des Sciences, Laboratoire sur l'Energie Solaire, BP 1515 Lomé, Togo; \\ tchamye@gmail.com, silnapo@yahoo.fr \\ ²Cirad, UMR Qualisud, TA B695/15, 34398 Montpellier Cedex 5, France; jean-michel.meot@cirad.fr \\ 3Université de Lomé, Ecole Supérieure d'Agronomie, Département de Génie rural et Machinisme agricole, \\ BP 1515 Lomé, Togo; azouma@yahoo.com \\ ${ }^{4}$ Université Claude Bernard de Lyon1, CNRS UMR 5007-CPE, Laboratoire d'Automatique et de Génie des Procédés, \\ 69622, Villeurbanne cédex, France; desmorieux@lagep.univ-lyon1.fr
}

\begin{abstract}
The reduction of the post-harvest loses that reaches $50 \%$ in the developing countries constitutes a major stake for their development. Then, it is right to make more efficient the processes of stabilization and conservation of products. The drying constitutes of a more used process but the mistakes committed in the choice of dryer in a given context entail important losses of products. As an approach of solution to this problem, we conceived and realized a decision making tool. An industrial engineering procedure has been led to analyze drying activities. The tool is informed by a data base containing the features of tropical products, the climatic environment and the construction supplies for dryers. The technical solutions describing the types of dryers have been counted from a technological watch over and analyzed using industrial engineering tools. The choice of indicators permits to value and to compare the different technical solutions. The implementation of the decision making tool in Visual Basic with Microsoft Excel software permits, from the input data, to size the technical solutions, and calculate the value of the indicators for the each technical solutions and to compare them one with another. An ex post validation of the tool has been made from the functional specifications of a SMAI of drying of pineapple in Lome, Togo. The better choice recommended by these specifications is the use of ATESTA dryers. The choice corresponds to the dryer used by the SMAI satisfaction. The rough idea of the development expenses and profitability are near of the reality. Although this validation is partial, the tool seems to have from now on, a worthwhile applicative interest.
\end{abstract}

Keywords: Design, Dryers Choice, Agricultural Produce, Technical Solution, Tropical Environment.

\section{Introduction}

The development of post-harvests transformations of the agricultural produce in the developing countries hold an important place in the reduction of the losses noted between the harvest and the consumption of the products. Indeed, these losses are estimated in average to $25 \%$ for the cereals and more than $50 \%$ for the fruits, vegetables and tubers [1].

${ }^{*}$ Corresponding author:

Tchamye Tcha-Esso Boroze (tchamye@gmail.com)
These losses have numerous reasons among which the "wrong way" of drying the products. The registered losses are due, in the majority of the cases, to the traditional drying practices and the use of dryers that do not meet the real needs of the users. To improve the choice of the dryers, some tools for decision making have been developed. These tools differ currently according to the categories of dryers. They are described on paper as chart, as classification tree, or are implemented on computer. 
The existing classifications of dryers propose for the industrial dryers for an example, an ordering of the dryers based on the tabulated criteria such as the mode of production, the state, the shape and the size of the product, the heat transfer mode to the product, the pressure of working and the circulation of the product $[2,3]$. The small and middle scale dryers are classified according to their principle of heat production and the type of convection [4]. Other principles for dryers such as design and realization are presented by Desmorieux [5]. Lists of dryers with photos, diagrams, indications on the cost of purchase and the dried products, have been established by Rozis [6], as well as specialized book on a particular product retailing its drying process and the adapted dryers [7]. One can also mention the models of laboratory, the scientific articles, a review on the dryers that have been conceived etc [8-10].

Edoun [11], proposed "MASADRY", a tool that can permit to determine the principles of solutions in design of dryers, taking into account the user's need in humid zone. However, besides its geographical limitation and its complexity, the tool is not going as far as proposing some technical solutions.

For computerized decision making tools, one can mention the use of the fuzzy logic theory by Baker and Lababidi [12], for the selection of batch dryers. The improved version with the use of the web permitted the development of "DrySES" application for the choice of the industrial dryers [13]. The selection criteria are the mode of operation, the disposition of the products in the dryer and the mode of contact between air and produces.

If the decision-making for the choice of industrial dryers is developed enough today with précised criteria and expert systems, it is not the same for the small and middle scale dryers, which are also used much. On this semi-industrial and artisanal scale, the classifications of the dryers don't provide sufficient information taking in account all aspects of the need of a dryer claimant. Most of existing classifications give information only on the dryers' principle of working, the capacity, the drying cycle duration and the cost of purchase. The information given is useful but greatly insufficient and lack precision to lead to a choice. Some require for their use, a higher level of instruction. Besides, none of these existing tools included the aspect of design of the dryers. All are oriented toward the choice of existing dryers.

As an answer to the insufficiency of the existing tools, our work describes the methodology of development of a new tool: the Decision making for designing and Choice for Agricultural crop Dryers tool (DMDCAD). It is based on a multi-criterion approach taking into account the different parameters influencing the working of a dryer. Finally, the obtained results as well as an ex post validation of the "DMDCAD tool" are presented.

\section{Methodology of Development of the "DMDCAD Tool"}

\subsection{General Organization of the Tool}

The procedure followed to determine the most adequate solution for the multicriterion problem to solve, is declined in 3 stages by Roy [14]:

i. Drawing up the list of the potential actions, this corresponds to the technical solutions capable to be use to realize the dryers;

ii. Drawing up the list of the criteria to be taken in consideration; these criteria are the indicators whose value will permit the choice of a technical solution rather than another;

iii. Establishing the table of the performances that implicates to determine how the indicators are valued.

The result of the "DMDCAD tool" presents the fundamental information for each technical solution in order to lead the user of the tool in his decision making. With that information, it is up to the user to make the final choice. The Figure 1 shows a descriptive diagram of the tool.

\subsection{Data about Users}

The user's data concerns of the specifications that the dryer must meet. It is the necessary information to get from a claimant of dryer and it is about: the product to be dried, the wished daily flow rate of the product to be dried, the cost of the raw and the dried product, as well as the precision on the period of use of the dryer during the year and the geographical localization to deduce the climatic parameters.

\subsection{The Data Base}

\subsubsection{Data on the Products}

The products in the data base are the tropical agricultural produce: cereals, tubers, vegetables and fruits. The 


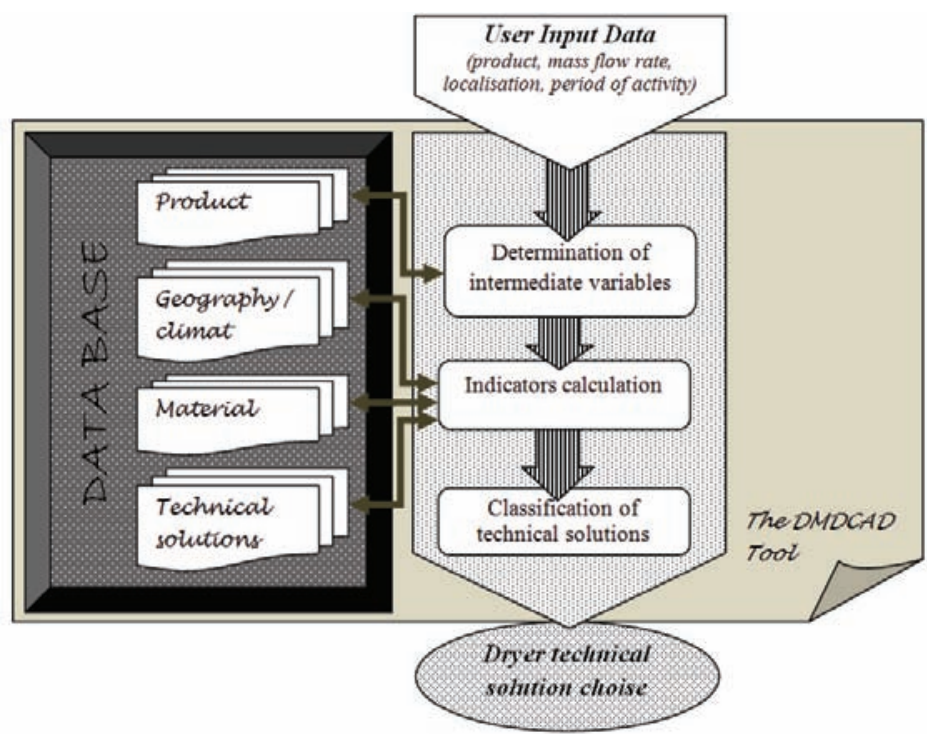

Figure 1. General presentation of the "DMCAD tool".

recorded data concern: the initial and final moisture content, the minimal and maximal thickness of the product layer, the shape under which the product is commonly dried, it specific mass and sugar content. These data have been provided from the literature (moisture and sugar content, drying efficiency), from survey results (shapes, thickness of the agricultural product layers) and from laboratory experiments (moisture content, specific mass, mass ratio between the prepared product to be dried and the raw one).

\subsubsection{Data on the Climatic Environment}

The data base informs on the global solar radiation, the temperature and the relative humidity of the ambient air. The current recorded data are those of three localities of Togo characterizing three (3) types of climates in the West-African region: Lome in the south for the humid tropical climate, Atakpamé in the center for the Sudanese tropical climate and Mango in the north for the Sudan-sahelian tropical climate. These data result from monthly averages of measures done on one hand by the UNESCO chair on the renewable energies of university of Lome for the solar radiation [15] and on the other hand by the national service of meteorology for temperature and humidity data.

The global solar radiation is measured on the ground with pyranometer LI 200 SA with precision of 5\% connected to LI1400 central made by LICOR.
The temperatures are measured by thermometers with a precision of $\pm 0,1^{\circ} \mathrm{C}$. The relative humidity is measured from a hygrometer of $6 \%$ of precision. All the collected data have been calculated with the Microsoft Excel software.

\subsubsection{Data on the Materials for Dryer Construction}

The quasi-totality of the materials intervening in the realization of dryer has been listed. It is about materials made of wood, steel, glass, plastic film, etc. The price of these materials has been raised on different markets in Lome in 2013. According to the characteristic measurements of the aforesaid materials, the price have been calculated in $\mathrm{f} \mathrm{CFA} / \mathrm{kg}$ for the bars of steels, of aluminum, etc.; in $\mathrm{f} \mathrm{CFA} / \mathrm{m}^{2}$ for the sheet metal, the wire fencings, etc. and in $\mathrm{fCFA} / \mathrm{m}$ for the tubes and the sections.

\subsubsection{The Technical Solutions for Dryers}

The determination of the technical solution left from a review of the literature to take into account all dryers that are presented and from investigations achieved in three countries of west-Africa (Togo, Benin and BurkinaFaso) to list the existing dryers and those who are still used. To these two sources, are added the creativeness and the experience of the research team. The approach used for this determination is described by the Figure 2 . 


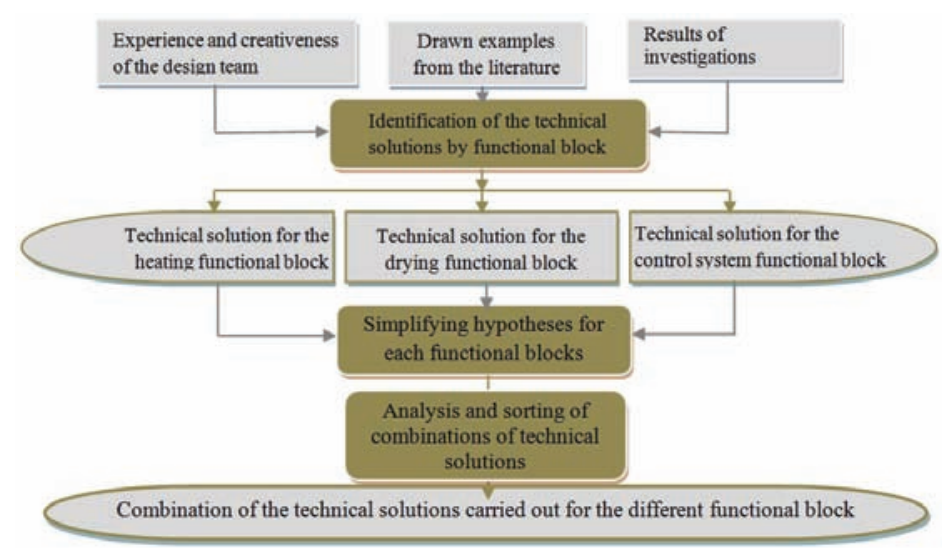

Figure 2. Procedure for determination of the retained technical solutions.

On each identified dryer, we proceed to determine the technical solutions used by functional block in its conception. The work was limited to the artisanal and semi-industrial dryers. The technical solutions admit in the tool result from the combination between the technical solutions of the different functional blocks.

\subsection{The Intermediate Variables}

The intermediate variables are calculated from the user input data (Figure 1). They don't depend on the type of dryer but are technical parameters that allow to better characterize the information provided by the user. These intermediate variables are: the evaporative flow rate and the necessary energy per day.

The evaporative flow rate $\left(\mathrm{M}_{\mathrm{ev}}\right)$ in $\mathrm{kg}$ per day, has been evaluated by the equation (1).

$$
M_{c v}=\frac{m_{i}}{\Delta t_{c y}}\left(\frac{X_{i}-X_{f}}{1+X_{i}}\right)
$$

where, $\left(X_{i}\right)$ and $\left(X_{f}\right)$ designates the initial and final moisture content and $\Delta t_{c y}$ represent the drying cycle duration and $\left(m_{i}\right)$ the daily mass of product to be dry calculated by equation (2).

$$
m_{i}=\dot{M}_{j} \times \eta_{p r g}
$$

where, $M_{j}$ indicate the daily debit of raw product and $\eta_{p r g}$ the mass ratio between humid product to be dried and the raw product.

The necessary energy per day $\left(E_{\text {nec }}\right)$ for a given drying is evaluated by equation (3).

$$
E_{n e c}=\dot{M}_{e v} \times L_{V}
$$

$L_{\mathrm{v}}$ represents the latent heat of water vaporization.

Data used in the calculation of the intermediate variables by the tool are provided on one hand, by the users and on the other hand, by the integrated database that we constituted. The procedure diagram is shown on Figure 1.

\subsection{Determination of the Indicators of the Technical Solutions of the Tool}

The determination of the indicators considered during the development of the DMDCAD tool has been done referring to the survey results and the brainstorming which allowed pointing out the most applicable criteria for a user in the choice of a technical solution [16]. The teams having participated in the brainstorming are from the Unesco Chair of on renewable energy of university of Lome (CUER - UL, Togo), form the Laboratory of automatic device and genius of the processes of the university Claude Bernard of Lyons (LAGEP - UCBL1, France) and of the Mixed unit of Research (UMR) Qualisud of the International Center of Agronomic Research for the Development (CIRAD, France).

The qualitative and quantitative indicators are distributed in 4 categories: the indicators of performance, those economic, those related to the organization of work around the dryer, and those taking in account the environmental aspects and the marketing one. The indicators are calculated from intermediate variables that characterize the user's specifications. 


\subsection{Implementation}

The realized tool is implemented in Visual Basic programming language with Microsoft Excel 2007 software. Once the user's data are specified, the program calculates the intermediate variables, then determine for each technical solution the structuring measurements accordingly. This result combined with the costs of the different materials saved in the data base permits to have the estimated cost of the dryer.

\section{Results and Discussions}

\subsection{Data Base}

\subsubsection{Data on the Products}

The data base on the products concerns 22 products, distributed in 4 categories:

- cereals: corn, sorghum, rice;

- tubers: yam, cassava;

- fruits: banana, mango, pineapple, pawpaw;

- vegetables: tomato, peppers, bell pepper, okra, onion, garlic, ginger, carrot, cabbages; green bean, vegetables leaves, spirulina.

These data are presented in the Table 1 and give to the designer the information about the product he has to take into account to design a suitable dryer.

\subsubsection{Data on the Climatic Environment}

The climatic environment is processed in the tool from the data base and is characterized by data of solar radiation, temperature and relative humidity. The average monthly and yearly solar radiation values, the minimal, middle and maximal values of the temperature and the relative humidity are specified. The Table 2 presents these data for the cities of Lome, Atakpamé and Mango situated in the three (3) climatic regions in Togo and in many other countries in West Africa.

\subsubsection{Data on the Materials of Realization of Dryers}

The materials commonly used in the realization of dryers are also recorded in the data base. These materials have been characterized by their economic value by unit of mass, or length, or surface, or volume according to the type of material. The inventoried and treated data for the materials are presented in the Table 3 with the corresponding units.

\subsubsection{Technical Solutions Simulated by the Tool}

The technical solutions retained, coming out of the procedure presented on the Figure 2 are 17, for this first version of the tool. The Table 4 presents their description as well as the dryers on which, they have been already implemented. It has specified the source of energy used, the type of convection, the relative disposition of the hurdles, and in the case where they were used, the type of transparent cover used.

\subsection{Presentation and Working of the Tool}

The codes of calculation of the tool are written in Visual Basic and integrated in the Microsoft Excel software. The tool includes two user-interfaces, one for the input data and the other for the results.

\subsubsection{Interface Data Entry}

It is achieved from an Excel sheet and allows the user to introduce in the tool data characterizing his need. The interface allows to specify information about the product, the climate in the geographical zone of drying and the cost of the material for the realization of the dryer and the hand of work. This interface is presented on Figure 3.

The unwinding lists allow for instance, while choosing a product for example, to fill automatically, from the data base, the other linked cells (initial, final and critical moisture content). The cells in black are to be filled by the user of the tool. Those in pale color are provided from the data base, but can be modified by the user. The intermediate variables calculated by the tool and bringing interesting information on the activity appears in the blank cells. Two control buttons appear on this interface. The first: "RESET", allows to reinitialize the tool before every simulation and the second: "ACHIEVE DRYER CALCULATION" to order the simulation and display the results. The results are displayed in another Excel sheet, which is the interface of simulations result. During the calculation that is fast enough, an indication "CALCULATION IN PROGRESS" shows off on the screen. 
Table 1. Data base on the products

\begin{tabular}{|c|c|c|c|c|c|c|c|c|c|c|c|}
\hline Product $^{1}$ & Shape & $\begin{array}{c}\text { Average } \\
\text { initial } \\
\text { moisture } \\
\text { content } \mathrm{X}_{\mathrm{i}} \\
(\%)\end{array}$ & $\begin{array}{c}\text { Average } \\
\text { final } \\
\text { moisture } \\
\text { content } \mathrm{X}_{\mathrm{f}} \\
(\%)\end{array}$ & $\begin{array}{l}\text { Masse ratio } \\
\text { for raw } \\
\text { product } \\
\text { preparation }\end{array}$ & $\begin{array}{l}\text { Specific } \\
\text { mass } \\
(\mathrm{kg} / \mathrm{m} 3)\end{array}$ & $\begin{array}{l}\text { Sugar } \\
\text { content } \\
(\mathrm{g} / 100 \mathrm{~g})\end{array}$ & $\begin{array}{l}\text { Max tem- } \\
\text { perature } \\
\quad\left({ }^{\circ} \mathrm{C}\right)\end{array}$ & $\begin{array}{c}\text { Min } \\
\text { diameter } \\
(\mathrm{cm})\end{array}$ & $\begin{array}{c}\text { Max } \\
\text { diameter } \\
(\mathrm{cm})\end{array}$ & $\begin{array}{l}\text { Min } \\
\text { thickness } \\
(\mathrm{cm})\end{array}$ & $\begin{array}{c}\text { Max } \\
\text { thickness } \\
(\mathrm{cm})\end{array}$ \\
\hline $\begin{array}{l}\text { Corn }(24-35 \%-> \\
12-15 \%)\end{array}$ & grains & $30 \%$ & $14 \%$ & $100 \%$ & 0,2 & 3,64 & 60 & & & 3 & 7,5 \\
\hline Rice $(24 \%->11 \%)$ & grains & $24 \%$ & $11 \%$ & $100 \%$ & 0,2 & 0,13 & 50 & & & & 2,5 \\
\hline $\begin{array}{l}\text { Sorghum, millet } \\
(21 \%->14 \%)\end{array}$ & grains & $21 \%$ & $14 \%$ & $100 \%$ & 0,2 & & & & & 1,5 & 6,5 \\
\hline $\begin{array}{l}\text { Yam }(70-80 \%-> \\
10-14 \%)\end{array}$ & slices & $75 \%$ & $12 \%$ & $100 \%$ & 4 & $5,8-7,2$ & 65 & & & 4 & 7,5 \\
\hline $\begin{array}{l}\text { Cassava }(62-70 \% \\
->10-17 \%)\end{array}$ & slices & $66 \%$ & $13 \%$ & $100 \%$ & 4,5 & 3,9 & & & & 4 & 7 \\
\hline $\begin{array}{l}\text { Pineapple ( } 80- \\
85 \% \text {-> 10-12\%) }\end{array}$ & slices & $83 \%$ & $11 \%$ & $30 \%$ & 5 & $6,4-14$ & 65 & & & 3 & 7 \\
\hline $\begin{array}{l}\text { Banana }(72-80 \% \\
->12-15 \%)\end{array}$ & slices & $76 \%$ & $14 \%$ & $100 \%$ & 5 & $14,8-27$ & 70 & 3 & 3,5 & 0,5 & 4 \\
\hline $\begin{array}{l}\text { Mango ( } 80 \% \text {-> } \\
12-16 \%)\end{array}$ & slices & $80 \%$ & $14 \%$ & $50 \%$ & 6 & $13-16$ & 70 & 0,5 & 1,5 & & \\
\hline $\begin{array}{l}\text { Pawpaw (80\% -> } \\
12-16 \%)\end{array}$ & slices & $80 \%$ & $14 \%$ & $100 \%$ & 6 & $7,6-7,8$ & 70 & & & & \\
\hline $\begin{array}{l}\text { Cabbages }(80 \% \\
->5 \%)\end{array}$ & slices & $80 \%$ & $5 \%$ & $100 \%$ & 2 & $2,8-3$ & $60-65$ & & & & \\
\hline $\begin{array}{l}\text { Carrot (70\% -> } \\
5 \%)\end{array}$ & slices & $70 \%$ & $5 \%$ & $100 \%$ & 3 & 6,7 & 75 & 2,5 & & 2 & \\
\hline $\begin{array}{l}\text { Tomato (95\% -> } \\
7 \%)\end{array}$ & slices & $95 \%$ & $7 \%$ & $100 \%$ & 3 & $2,8-3,5$ & $50-60$ & & & & \\
\hline $\begin{array}{l}\text { Pepper, bell } \\
\text { pepper }(71-85 \% \\
->5-13 \%)\end{array}$ & pieces & $78 \%$ & $9 \%$ & $100 \%$ & 1 & $2,2-4,7$ & 70 & 1,5 & 4 & 2 & 5 \\
\hline $\begin{array}{l}\text { Onion, garlic ( } 80- \\
85 \%->4 \%)\end{array}$ & pieces & $82 \%$ & $4 \%$ & $100 \%$ & 2 & $7,1-8,2$ & 55 & 3 & 7,5 & & \\
\hline $\begin{array}{l}\text { Green bean }(70 \% \\
->5 \%)\end{array}$ & $\begin{array}{l}\text { pieces, } \\
\text { entirely }\end{array}$ & $70 \%$ & $5 \%$ & $100 \%$ & 3 & $2,6-4,6$ & 75 & 4,5 & 7 & 0,4 & 0,7 \\
\hline $\begin{array}{l}\text { Okra }(80-87 \%-> \\
11-20 \%)\end{array}$ & $\begin{array}{l}\text { pieces, } \\
\text { entirely }\end{array}$ & $83 \%$ & $15 \%$ & $100 \%$ & 4 & 5,5 & 66 & 2,5 & 4 & 3 & 4,5 \\
\hline $\begin{array}{l}\text { Ginger ( } 80 \%-> \\
10 \%)\end{array}$ & $\begin{array}{l}\text { pieces, } \\
\text { entirely }\end{array}$ & $80 \%$ & $10 \%$ & $100 \%$ & & 9,8 & & & & & \\
\hline $\begin{array}{l}\text { Vegetable leaves } \\
(80 \%->10 \%)\end{array}$ & leaves & $80 \%$ & $10 \%$ & $100 \%$ & & & 60 & & & & 4 \\
\hline $\begin{array}{l}\text { Spirulina (micro- } \\
\text { alga) }(80 \%->8 \%)\end{array}$ & fibers & $80 \%$ & $8 \%$ & $100 \%$ & & & $40-60$ & & & & \\
\hline
\end{tabular}

${ }^{1}$ Product: (range of initial and final moisture content)

\subsubsection{Interface of Simulations Result}

The interface of simulations result is presented as a table showing on the lines, the technical solutions defined in the tool, and in to the columns, the values of the indicators (quantitative or qualitative). A preview is presented on the Figure 4. This result sheet presents to the user all structuring information to permit to make the choice of a technical solution. This conceived tool doesn't force to a specific choice but presents the values of the indicators in the decision making. These values are presented elsewhere in the existing tools for dryers design or choice. The user can make with the tool an automatic classification of the solutions following such or such indicator which is more convincing. However this process brings 
Table 2. Climatic data base of the environment ${ }^{2}$

\begin{tabular}{|c|c|c|c|c|c|c|c|c|c|c|c|c|c|}
\hline Month & $\begin{array}{l}\text { Annual } \\
\text { average }\end{array}$ & January & February & March & April & May & June & July & August & September & October & November & December \\
\hline \multicolumn{14}{|l|}{ Lome } \\
\hline \multicolumn{14}{|l|}{ Solar } \\
\hline $\begin{array}{l}\text { radiation } \\
\left(\mathrm{kWh} / \mathrm{m}^{2} . \mathrm{j}\right)\end{array}$ & 4,4 & 3,7 & 4,2 & 4,9 & 4,9 & 4,6 & 3,8 & 4,2 & 4,1 & 4,5 & 4,8 & 4,9 & 4,3 \\
\hline $\operatorname{Min} \mathrm{T}^{\circ}$ & 25 & 24 & 26 & 26 & 26 & 25 & 24 & 24 & 24 & 24 & 24 & 25 & 25 \\
\hline $\operatorname{Max}^{\circ}$ & 32 & 32 & 33 & 33 & 33 & 32 & 30 & 29 & 29 & 30 & 31 & 33 & 33 \\
\hline Mean $\mathrm{T}^{\circ}$ & 28 & 28 & 30 & 30 & 29 & 29 & 27 & 27 & 26 & 27 & 28 & 29 & 29 \\
\hline Min HR & $66 \%$ & $54 \%$ & $63 \%$ & $62 \%$ & $65 \%$ & $66 \%$ & $71 \%$ & $73 \%$ & $74 \%$ & $72 \%$ & $68 \%$ & $63 \%$ & $58 \%$ \\
\hline Max HR & $94 \%$ & $93 \%$ & $93 \%$ & $92 \%$ & $93 \%$ & $95 \%$ & $96 \%$ & $95 \%$ & $95 \%$ & $95 \%$ & $96 \%$ & $95 \%$ & $95 \%$ \\
\hline Mean HR & $80 \%$ & $74 \%$ & $78 \%$ & $77 \%$ & $79 \%$ & $81 \%$ & $84 \%$ & $84 \%$ & $80 \%$ & $84 \%$ & $82 \%$ & $79 \%$ & $76 \%$ \\
\hline \multicolumn{14}{|l|}{ Atakpame } \\
\hline \multicolumn{14}{|l|}{ Solar } \\
\hline \multicolumn{13}{|l|}{$\left(\mathrm{kWh} / \mathrm{m}^{2} . \mathrm{j}\right)$} & 4,6 \\
\hline $\operatorname{Min} \mathrm{T}^{\circ}$ & 22 & 22 & 23 & 23 & 23 & 22 & 22 & 21 & 21 & 21 & 21 & 22 & 22 \\
\hline $\operatorname{Max} \mathrm{T}^{\circ}$ & 32 & 33 & 36 & 35 & 33 & 32 & 30 & 29 & 28 & 30 & 31 & 33 & 33 \\
\hline Mean $\mathrm{T}^{\circ}$ & 27 & 28 & 29 & 29 & 27 & 27 & 23 & 25 & 25 & 25 & 26 & 27 & 28 \\
\hline Min HR & $50 \%$ & $24 \%$ & $30 \%$ & $38 \%$ & $51 \%$ & $58 \%$ & $64 \%$ & $68 \%$ & $69 \%$ & $65 \%$ & $59 \%$ & $42 \%$ & $31 \%$ \\
\hline Max HR & $91 \%$ & $66 \%$ & $85 \%$ & $88 \%$ & $94 \%$ & $96 \%$ & $97 \%$ & $98 \%$ & $98 \%$ & $98 \%$ & $97 \%$ & $91 \%$ & $81 \%$ \\
\hline Mean HR & $70 \%$ & $45 \%$ & $58 \%$ & $63 \%$ & $72 \%$ & $77 \%$ & $80 \%$ & $83 \%$ & $83 \%$ & $81 \%$ & $78 \%$ & $67 \%$ & $56 \%$ \\
\hline \multicolumn{14}{|l|}{ Mango } \\
\hline \multicolumn{14}{|l|}{ Solar } \\
\hline $\begin{array}{l}\text { radiation } \\
\left(\mathrm{kWh} / \mathrm{m}^{2} . \mathrm{j}\right)\end{array}$ & 5,3 & 5,4 & 5,9 & 6,0 & 5,8 & 5,3 & 4,8 & 4,4 & 4,4 & 5,1 & 5,8 & 5,4 & 5,2 \\
\hline $\operatorname{Min} \mathrm{T}^{\circ}$ & 23 & 20 & 23 & 26 & 27 & 25 & 24 & 23 & 23 & 23 & 23 & 21 & 20 \\
\hline $\operatorname{Max} \mathrm{T}^{\circ}$ & 36 & 36 & 38 & 40 & 38 & 36 & 33 & 32 & 32 & 33 & 36 & 38 & 37 \\
\hline Mean $\mathrm{T}^{\circ}$ & 29 & 28 & 31 & 33 & 32 & 31 & 28 & 27 & 27 & 28 & 29 & 30 & 28 \\
\hline Min HR & $43 \%$ & $22 \%$ & $20 \%$ & $25 \%$ & $42 \%$ & $49 \%$ & $60 \%$ & $64 \%$ & $69 \%$ & $64 \%$ & $49 \%$ & $30 \%$ & $20 \%$ \\
\hline Max HR & $78 \%$ & $36 \%$ & $45 \%$ & $63 \%$ & $82 \%$ & $88 \%$ & $96 \%$ & $98 \%$ & $99 \%$ & $99 \%$ & $96 \%$ & $79 \%$ & $53 \%$ \\
\hline Mean HR & $60 \%$ & $29 \%$ & $32 \%$ & $44 \%$ & $62 \%$ & $68 \%$ & $78 \%$ & $81 \%$ & $84 \%$ & $82 \%$ & $73 \%$ & $54 \%$ & $37 \%$ \\
\hline
\end{tabular}

a solid help to the decision, it does not force the designer to adopt a given stationary solution. He will be able to decide what is more convenient for his situation.

\subsection{Validation of the DMDCAD Tool: study of a Case of a Small and Medium Agro-food Industry (SMAI)}

\subsubsection{Presentation and Functional Specifications of the SMAI}

An ex-post validation of the decision making tool have been achieved on the specification of a SMAI situated in Lome in Togo. This SMAI dries biologic pineapple for export selling. The SMAI uses the Atesta dryers operating 24h/24 during 6 to 12 months per year.

The dryers operate by batch and in 2 phases: the first phase at $80^{\circ} \mathrm{C}$ for 10 to 12 hours, corresponding to the evaporation of the free water and the second phase at $45^{\circ} \mathrm{C}$ also for 10 to 12 hours. A permutation of the hurdles every hour allows to homogenize the drying of the products. The conduct of the drying is assured by 2 people taking turns every 12 hours. The raw material is bought from biologic pineapple producers' cooperatives in Togo.

The functional specifications describing the expectations of the enterprise, in terms of functions, has been achieved with the users to ascertain the effective processed of their need. User's entry data are presented in Table 5. 
Table 3. Data on materials

\begin{tabular}{|c|c|c|c|}
\hline \multicolumn{2}{|r|}{ Materials } & \multicolumn{2}{|c|}{ Cost of materials in Togo 2013} \\
\hline \multirow[t]{9}{*}{ Metals } & Steel (density 7.8 kg/ $\mathrm{dm}^{3}$ ) & & \\
\hline & Sheet metal & 705 & $\mathrm{fCFA} / \mathrm{m}^{2}$ \\
\hline & Square bar & 494 & $\mathrm{fCFA} / \mathrm{kg}$ \\
\hline & Angle iron & 182 & $\mathrm{f} C F A / \mathrm{kg}$ \\
\hline & Round tube & 334 & $\mathrm{f}$ CFA $/ \mathrm{kg}$ \\
\hline & Iron to concrete & 161 & $\mathrm{fCFA} / \mathrm{kg}$ \\
\hline & Galva Sheet metal & 1141 & $\mathrm{fCFA} / \mathrm{m}^{2}$ \\
\hline & Galva corrugated iron roofing & 1322 & $\mathrm{fCFA} / \mathrm{m}^{2}$ \\
\hline & Aluminum Sheet metal & 3721 & $\mathrm{fCFA} / \mathrm{m}^{2}$ \\
\hline Wood & Plant beam ( $\varnothing 25 \mathrm{~mm}$ ) & 500 & $\mathrm{fCFA} / \mathrm{m}$ \\
\hline & White wood & & \\
\hline & Board (17 mm of thickness) & 50 & $\mathrm{fCFA} / \mathrm{m}^{2}$ \\
\hline & Rafter $(6 \times 8 \mathrm{~cm})$ & 55 & $\mathrm{fCFA} / \mathrm{m}$ \\
\hline & Plywood & 257 & $\mathrm{f}$ CFA $/ \mathrm{m}^{2}$ \\
\hline \multicolumn{4}{|c|}{ Transparent cover } \\
\hline & $\begin{array}{l}\text { Glass } \\
\text { Plexiglas }\end{array}$ & $\begin{array}{l}3250 \\
3920\end{array}$ & $\begin{array}{l}\mathrm{f} C F A / \mathrm{m}^{2} \\
\mathrm{fCFA} / \mathrm{m}^{2}\end{array}$ \\
\hline & Polyethylene & 500 & $\mathrm{fCFA} / \mathrm{m}^{2}$ \\
\hline Insulat & Glass wool & 150 & $\mathrm{fCFA} / \mathrm{dm}^{3}$ \\
\hline & Kapok & 30 & $\mathrm{f} C F A / \mathrm{dm}^{3}$ \\
\hline Grid hurdles & Plant furniture & 30 & $\mathrm{fCFA} / \mathrm{m}^{2}$ \\
\hline & Texture ties & 150 & $\mathrm{fCFA} / \mathrm{m}^{2}$ \\
\hline & Wire fencing in plastic & 412 & $\mathrm{fCFA} / \mathrm{m}^{2}$ \\
\hline & Classic wire fencing & 1000 & $\mathrm{fCFA} / \mathrm{m}^{2}$ \\
\hline & Wire fencing in galva (stitch of $1 \times 1 \mathrm{~cm}$ ) & 833 & $\mathrm{fCFA} / \mathrm{m}^{2}$ \\
\hline & Wire fencing in alu (stitch of $1 \times 1 \mathrm{~cm}$ ) & 1444 & $\mathrm{fCFA} / \mathrm{m}^{2}$ \\
\hline & \multicolumn{2}{|l|}{ 10igeater bated } & $\mathrm{fCFA} / \mathrm{m}^{2}$ \\
\hline Dumt & Base plate in clay & 40 & $\mathrm{fCFA} / \mathrm{m}^{3}$ \\
\hline & concrete tile & 100 & $\mathrm{fCFA} / \mathrm{m}^{2}$ \\
\hline & Wall in cement & 60 & $\mathrm{fCFA} / \mathrm{m}^{2}$ \\
\hline & Wall in clay & 40 & $\mathrm{fCFA} / \mathrm{m}^{2}$ \\
\hline
\end{tabular}

Table 4. Technical solutions and models of dryers corresponding

\begin{tabular}{|c|c|c|c|c|c|}
\hline $\mathrm{N}^{\circ}$ & Dryer & Cover & Type of convection & $\begin{array}{c}\text { Disposition of the } \\
\text { hurdles }\end{array}$ & $\begin{array}{c}\text { Example of } \\
\text { dryer }\end{array}$ \\
\hline 1. & & Without protection & Natural convection & extended & Area cemented \\
\hline 2. & Area of drying & Without protection & Natural convection & extended & Awning \\
\hline 3. & & With cloths cover & Natural convection & extended & Awning \\
\hline 4. & $\begin{array}{l}\text { Area of drying } \\
\text { raised }\end{array}$ & Without protection & Natural convection & extended & Hurdles raised \\
\hline 5. & & With cover & Natural convection & extended & Hurdles raised \\
\hline 6. & & Polyethylene & Natural convection & extended & Tent \\
\hline 7. & Solar direct & Polyethylene & Natural convection & extended & Case, slot \\
\hline 8. & & Polyethylene & Natural convection & extended & Greenhouse \\
\hline 9. & Indirect & without cover & Cheminey & superimposed & Indirect \\
\hline 10. & Indirect + gas & without cover & Natural convection & superimposed & Indirect + gas \\
\hline 11. & Indirect & Glass & Natural convection & superimposed & MO5 \\
\hline 12. & Indirect + gas & Glass & Natural convection & superimposed & MO5 + gas \\
\hline 13. & Mixed & Glass & Cheminey & extended & Room \\
\hline 14. & Mixed & Glass & Forced convection & extended & Hohenheim \\
\hline 15. & Mixed + gas & Glass & Cheminey & extended & Room + gas \\
\hline 16. & Gas & - & Natural convection & superimposed & Atesta \\
\hline 17. & Gas + solar & Glass & Forced convection & extended & Geho \\
\hline
\end{tabular}




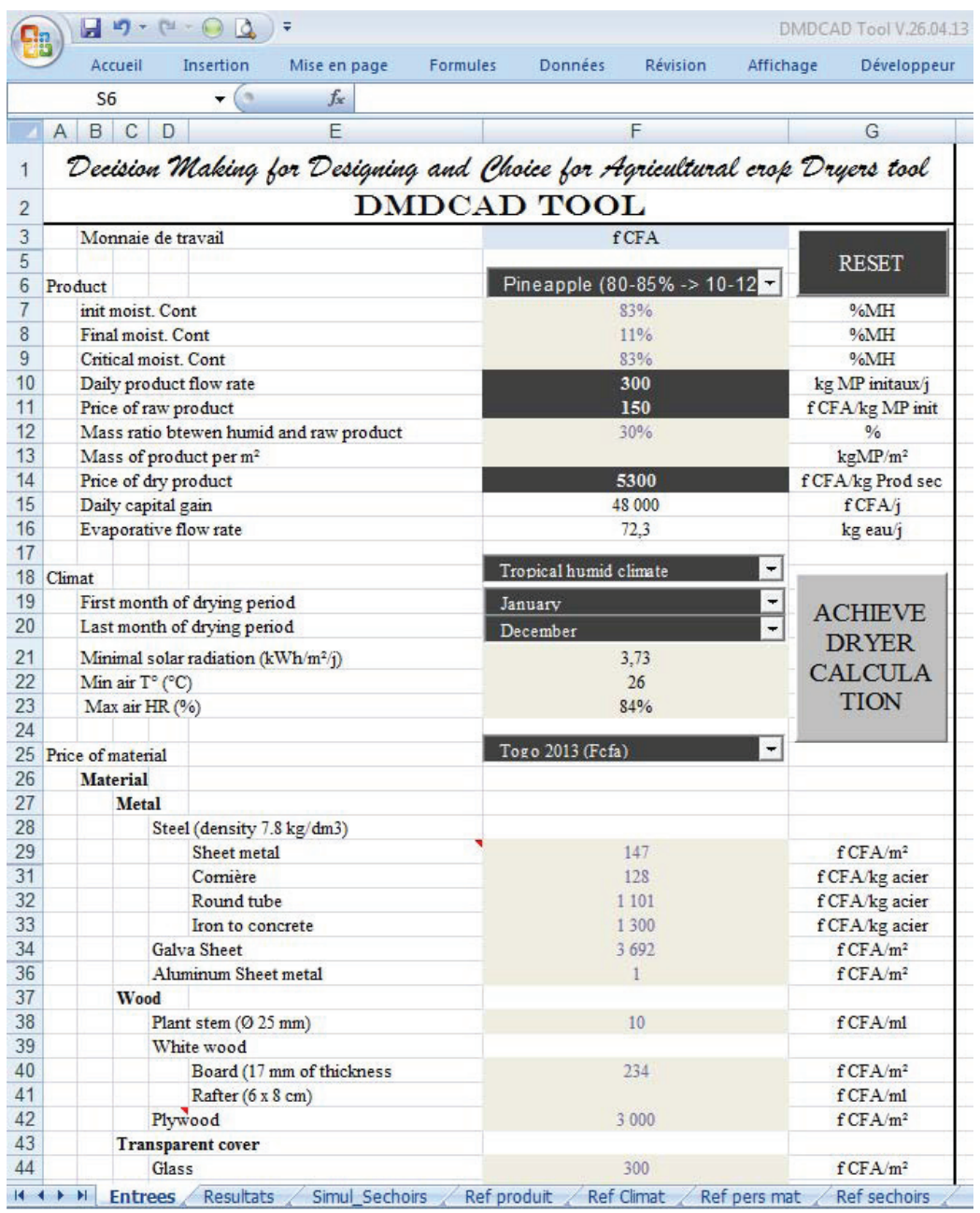

Figure 3. User Input Data Interface.

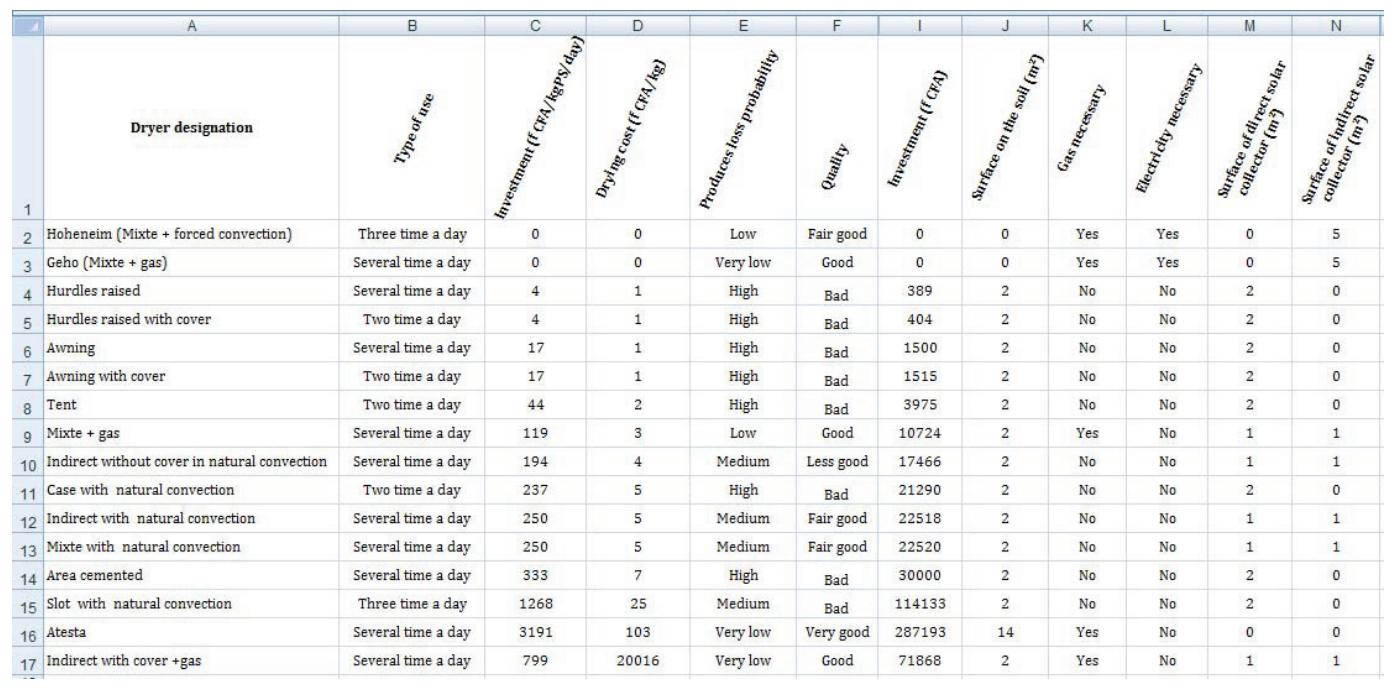

Figure 4. User-interface results of the simulation. 
Table 5. User's entry data completing the functional specifications of the SMAI

\begin{tabular}{ll}
\hline \multicolumn{1}{c}{ User data } & \multicolumn{1}{c}{ Values } \\
\hline Daily debit of product & $300 \mathrm{~kg}$ \\
Price of the raw material & $130-215 \mathrm{fCFA}$ \\
$\begin{array}{l}\text { Price of the dry product } \\
\text { Beginning of yearly period of }\end{array}$ & $5300 \mathrm{fCFA}$ \\
activity & January \\
$\begin{array}{l}\text { End of yearly period of activity } \\
\text { Climate in the activity zone }\end{array}$ & $\begin{array}{l}\text { December } \\
\text { tropical humid }\end{array}$ \\
\hline
\end{tabular}

\subsubsection{Discussion of the Validation Results}

A simulation to determine the type of dryer that would correspond the most for the SMAI permits to get the result presented in the Table 6 . The results are classified by ascending order of the cost of drying by $\mathrm{kg}$ of dry product. It appears that only one criterion is insufficient to make the choice. Rather a compromise is necessary between different indicators.

By ascending order of the drying cost, the "Mixed technical solution + gas" indicating a mixed solar dryer using a gas energy sometimes, is put in top, followed by the technical solutions "Indirect without or with cover" and then comes the free air drying solutions like the drying on "stilted hurdles with or without cover" and on "awning". The solution of drying with gas energy only, the "Atesta", used in the SMAI is classified in $10^{\text {th }}$ position in relation with the cost of the drying by kg of dry product. The drying cost of the free air drying devices, having a very low operating cost is nearly equal to the amortization cost of the equipment. In this case of pineapple drying (with a high initial moisture content), the daily product flow rate of $300 \mathrm{~kg}$ /day point out by the user, lead to a wide surfaces of $121 \mathrm{~m}^{2}$ for the free air drying. This drives to high elevated amortization cost. The "Mixed + gas" technical solution allows improving the solar energy collect by the use of direct and indirect solar collector. Then, the presence of gas allows to replace the solar energy in case of insufficiency. The double solar collector system in the mixed mode dryer and a proper use of gas, drives to minimize the cost of drying. The technical solution using only gas, "Atesta" comes in $10^{\text {th }}$ position because of the very high operating cost, due to the use of gas only.

On the viewpoint of the initial investment cost, the traditional solutions are least expensive. We can also notice that those using the combustion of gas are not necessarily the most expensive, contrary to what we can think. They are classified in the $4^{\text {th }}, 10^{\text {th }}, 13^{\text {th }}$ and $17^{\text {th }}$ position respectively for "Mixed + gas", "Indirect + gas", "Atesta" and the "Geho", in the increasing order of the investment cost. Moreover, in the same order, of the drying cost, they are in $2^{\text {nd }}, 10^{\text {th }}, 16^{\text {th }}$ and $17^{\text {th }}$ position. The initial investment cost is calculated according to the measurements of the different technical solutions, the types of materials used and their quantity.

With regards to the quality of the dry product, the use of gas is recommended by the tool. The "Atesta" dryer is classified in first position. Then come the mixed mode dryers using gas, indirect with gas, mixed, indirect and direct dryers without the use of gas and finally the traditional devices. These last give bad qualities of dry products for pineapple which have high initial moisture content. With these devices, the drying flow rate is very low, so the products are contaminated by the bugs, the dust, etc. All these factors increase the probability of loss of product for the traditional drying devices as shown on the results of the tool.

To hierarchize the indicators, we conformed to the user's priorities. The constraints on the shape of the dry product and the requirements of the market of the dry products are mentioned in first position. Then, the economic criteria follows. Being in commercial fields, the losses of products must be reduced as much as possible. And finally, being located in urban area, the surface occupied by the selected dryer must also be reduced. The ordering of the technical solutions resulting from this hierarchization of indicators is given in the Table 6.

The technical solution "Atesta" using the combustion of gas comes in first position. Followed respectively by "Geho (Mixte + Gas)" a hybrid dryer with ventilation system, "Indirect with cover + gas" and "Mixed + gas.", hybrid dryers without ventilation. Then, come dryers using only solar energy with ventilation or not and in final position, the traditional devices. The dryers currently used by the enterprise and with good satisfaction, according to the local dryers' technology, are "Atesta" dryers. From the results of the simulation of the tool on the specifications of this SMAI, we can say that the tool brings the necessary elements to orient the choice of technical solution in designing of dryer. On the basis of these results, we can, deduce that the finalized and simulated tool on the local dryers technologies and their variants, allows to orient efficiently the choice of a technical solution. The indicators provided by the tool are coherent for the analyzed situation and sufficient to make a choice. But this is facilitated 
because of the constraint on the area that must be occupied by the dryer and the localization of the enterprise in humid zone. In spite of this, it will be useful to elaborate a procedure that will allow to pass from indicators values to the choice. The improvement of the present tool will continue with the analysis of other drying situations.

\section{Conclusion}

The decision making tool presented was based on a previous survey of the drying activity and equipment conception approach. The tool provides for a given context a sizing of the different technical solutions and

Table 6. Hierarchization of technical solutions proposed by the DMDCAD tool for the SMAI

\begin{tabular}{|c|c|c|c|c|c|c|c|c|c|c|}
\hline Designation drier & Quality & $\begin{array}{l}\text { Produces } \\
\text { loss } \\
\text { probability }\end{array}$ & $\begin{array}{l}\text { Drying } \\
\text { cost } \\
\text { (fCFA/ } \\
\mathrm{kg} / \\
\text { day) }^{2}\end{array}$ & $\begin{array}{l}\text { Investment } \\
\text { (fCFA/kg/ } \\
\text { day) }\end{array}$ & $\begin{array}{l}\text { Type of } \\
\text { use }\end{array}$ & $\begin{array}{l}\text { Surface } \\
\text { on the } \\
\text { soil }\left(\mathrm{m}^{2}\right)\end{array}$ & $\begin{array}{l}\text { Direct } \\
\text { Solar } \\
\left(\mathrm{m}^{2}\right)\end{array}$ & $\begin{array}{l}\text { Indirect } \\
\text { Solar } \\
\left(\mathrm{m}^{2}\right)\end{array}$ & $\begin{array}{l}\text { Gas } \\
\text { necessary }\end{array}$ & $\begin{array}{l}\text { Electricity } \\
\text { necessary }\end{array}$ \\
\hline Atesta & Very good & Very low & 509 & 13138 & $\begin{array}{l}\text { Several } \\
\text { actions } / \mathrm{j}\end{array}$ & 14 & 0 & 0 & YES & $\mathrm{NO}$ \\
\hline $\begin{array}{l}\text { Geho (Mixed + } \\
\text { gas) }\end{array}$ & Good & Very low & 13395 & 221017 & $\begin{array}{l}\text { Several } \\
\text { actions/j }\end{array}$ & 56 & 43 & 5 & YES & YES \\
\hline $\begin{array}{l}\text { Indirect with +gaz } \\
\text { cover }\end{array}$ & Good & Very low & 20223 & 8731 & $\begin{array}{l}\text { Several } \\
\text { actions/j }\end{array}$ & 51 & 9 & 42 & YES & $\mathrm{NO}$ \\
\hline Mixed + gas & Good & Low & 105 & 2831 & $\begin{array}{l}\text { Several } \\
\text { actions } / j\end{array}$ & 51 & 9 & 42 & YES & $\mathrm{NO}$ \\
\hline $\begin{array}{l}\text { Indirect with cover } \\
\text { natural convection }\end{array}$ & Fair good & Medium & 167 & 5945 & $\begin{array}{l}\text { Several } \\
\text { actions/j }\end{array}$ & 51 & 9 & 42 & $\mathrm{NO}$ & $\mathrm{NO}$ \\
\hline $\begin{array}{l}\text { Hohenheim } \\
\text { (Mixed in forced } \\
\text { convection) }\end{array}$ & Fair good & Low & 12533 & 212961 & $\begin{array}{l}\text { Morning, } \\
\text { noon, } \\
\text { evening, }\end{array}$ & 56 & 43 & 5 & YES & YES \\
\hline $\begin{array}{l}\text { Mixed natural } \\
\text { convection }\end{array}$ & Fair good & Medium & 239 & 8579 & $\begin{array}{l}\text { Several } \\
\text { actions/j }\end{array}$ & 75 & 13 & 61 & $\mathrm{NO}$ & $\mathrm{NO}$ \\
\hline $\begin{array}{l}\text { Indirect without } \\
\text { cover natural } \\
\text { convection }\end{array}$ & Less good & Medium & 152 & 6049 & $\begin{array}{l}\text { Several } \\
\text { actions/j }\end{array}$ & 54 & 5 & 48 & NO & $\mathrm{NO}$ \\
\hline $\begin{array}{l}\text { Greenhouse } \\
\text { natural convection }\end{array}$ & Bad & Medium & 3805 & 189615 & $\begin{array}{l}\text { Morning, } \\
\text { noon, } \\
\text { evening, }\end{array}$ & 79 & 79 & 0 & $\mathrm{NO}$ & $\mathrm{NO}$ \\
\hline $\begin{array}{l}\text { Case in natural } \\
\text { convection }\end{array}$ & Bad & High & 494 & 7643 & $\begin{array}{l}\text { Morning } \\
\text { evening }\end{array}$ & 60 & 60 & 0 & $\mathrm{NO}$ & $\mathrm{NO}$ \\
\hline Tent & Bad & High & 522 & 9014 & $\begin{array}{l}\text { Morning } \\
\text { evening }\end{array}$ & 60 & 60 & 0 & $\mathrm{NO}$ & $\mathrm{NO}$ \\
\hline $\begin{array}{l}\text { Stilted hurdles } \\
\text { with cover cloth }\end{array}$ & Bad & High & 383 & 2084 & $\begin{array}{l}\text { Morning } \\
\text { evening }\end{array}$ & 121 & 121 & 0 & $\mathrm{NO}$ & $\mathrm{NO}$ \\
\hline $\begin{array}{l}\text { Awning with cover } \\
\text { cloth }\end{array}$ & $\mathrm{Bad}$ & High & 564 & 11100 & $\begin{array}{l}\text { Morning } \\
\text { evening }\end{array}$ & 151 & 151 & 0 & $\mathrm{NO}$ & $\mathrm{NO}$ \\
\hline Hurdles raised & Bad & High & 342 & 35 & $\begin{array}{l}\text { Several } \\
\text { actions } / \mathrm{j}\end{array}$ & 121 & 121 & 0 & $\mathrm{NO}$ & $\mathrm{NO}$ \\
\hline Awning & Bad & High & 410 & 6831 & $\begin{array}{l}\text { Several } \\
\text { actions } / j\end{array}$ & 121 & 121 & 0 & NO & $\mathrm{NO}$ \\
\hline Area cemented & Bad & High & 2732 & 136614 & $\begin{array}{l}\text { Several } \\
\text { actions/j }\end{array}$ & 121 & 121 & 0 & NO & $\mathrm{NO}$ \\
\hline
\end{tabular}


calculates the value of quantitative and qualitative indicators necessary for the dryer choice making. Information brought by these indicators constitutes a major progress. The user has then necessary elements to make a choice. The tool has been used in the case of a SMAI for which drying the pineapple for export is the main activity. The results of the tool, while taking in account the functional specifications of the SMAI and while classifying the indicators following the important criteria namely the quality of dry product and the costs, recommend in foreground, a use of the "Atesta" dryer. The comparison of the answer of the tool and the equipment used by the SMAI, show its consistency and allows to validate the decision making tool elaborated. It is important to specify that the tool as elaborated does not force the user or the designer but provides him all necessary information to become aware of the advantages and the inconveniences of every technical solution. The tool is implemented in Visual Basic on Microsoft Excel software which is easily accessible and does not need specific knowledge for its use. The user input data may be provided by the dryer claimant or by the designer. The other data are proposed by the tool.

\section{Acknowledgment}

We sincerely congratulate the "Service de Coopération et d'Action Culturelle (SCAC)" of France Embassy in Togo, CIRAD of Montpellier in France and Université de Lomé in Togo for their financial and technical support to this work.

\section{References}

1. FAO (1989). Prevention of post-harvest food losses: Fruits, vegetables and root crops, a training manual, FAO Training Series, Rome, Italy.

2. Bimbenet J J (2002). Génie des procédés alimentaires-Des bases aux applications, Dunod Paris.

3. Mujumdar A S (2004). Guide to industrial drying: Principles, equipment and new developments, Color Publications Pvt, Mumbai India.
4. Ekechukwu O V, and Norton B (1999). Review of solarenergy drying systems II: an overview of solar drying technology, Energy Conversion and Management, vol 40(6), 615-655.

5. Desmorieux H (1992). Le séchage en zone subsaharienne: Une analyse technique à partir de réalités géographiques et humaines, Thesis at Institut National Polytechnique de Lorraine, Lorraine, France.

6. Rozis J-F (1995). Sécher des produits alimentaires: Technique, procédés, équipement, GRET, Le point sur, Paris.

7. Rivier M, Meot J-M et al. (2009). Le séchage des Mangues, Quae, Paris.

8. Murthy M V R (2009). A review of new technologies, models and experimental investigations of solar driers, Renewable and Sustainable Energy Reviews, vol 13(4), 835-844.

9. Sharma A, Chen C R et al. (2009). Solar-energy drying systems: a review, Renewable and Sustainable Energy Reviews, vol 13(6-7), 1185-1210.

10. Fudholi A, Sopian K et al. (2010). Review of solar dryers for agricultural and marine products, Renewable and Sustainable Energy Reviews, vol 14(1), 1-30.

11. Edoun M (2010). Développement d'un outil d'aide à la conception de procédés de séchage à petite échelle en zone tropicale humide, Thesis at Ecole Nationale Supérieure des Sciences Agro-Industrielles, Université de Ngaoundéré, Ngaoundéré, Cameroun.

12. Baker C G J, and Lababidi H M S (2001). Development in computer-aided dryer selection, Drying Technology, vol 19(8), 1851-1873.

13. Lababidi H M S, and Baker C G J (2003). Web-based expert system for food dryer selection, Computers and Chemical Engineering, vol 27(7), 997-1009.

14. Roy B (1985). Méthodologie multicritère d'aide à la décision, Economica, Paris.

15. Amou K A, Ouro-Djobo S et al. (2010). Solar irradiation in Togo, International Scientific Journal for Alternative Energy and Ecology, vol 2(82), 14-21.

16. Boroze T T-E, Azouma Y O et al. (2009). Intégration des outils du génie industriel dans l'optimisation de la conception de séchoirs pour les produits agroalimentaires en climat tropical, Science et technique, Sciences appliquées et Technologies, vol 3(1-2), 45-60. 